\title{
Reinforcement of Recycled Aggregate by Microbial-Induced Mineralization and Deposition of Calcium Carbonate-Influencing Factors, Mechanism and Effect of Reinforcement
}

\author{
Chunhua Feng *, Buwen Cui, Haidong Ge, Yihong Huang, Wenyan Zhang and Jianping Zhu
}

Citation: Feng, C.; Cui, B.; Ge, H.; Huang, Y.; Zhang, W.; Zhu, J.

Reinforcement of Recycled Aggregate by Microbial-Induced Mineralization and Deposition of Calcium Carbonate-Influencing Factors,

Mechanism and Effect of

Reinforcement. Crystals 2021, 11, 887. https: / / doi.org/10.3390/ cryst11080887

Academic Editors: Hamed

\section{Khodadadi Tirkolaei,}

Satoru Kawasaki, Liang Cheng, Leon van Paassen and José L. Arias

Received: 29 June 2021

Accepted: 26 July 2021

Published: 30 July 2021

Publisher's Note: MDPI stays neutral with regard to jurisdictional claims in published maps and institutional affiliations.

Copyright: (C) 2021 by the authors. Licensee MDPI, Basel, Switzerland. This article is an open access article distributed under the terms and conditions of the Creative Commons Attribution (CC BY) license (https:// creativecommons.org/licenses/by/ $4.0 /)$.
School of Materials Science and Engineering, Henan Polytechnic University, Jiaozuo 454000, China; 211906020032@home.hpu.edu.cn (B.C.); ghd2417718886@126.com (H.G.); huangyihong@home.hpu.edu.cn (Y.H.); zhangwy@hpu.edu.cn (W.Z.); jianpingzhu@hpu.edu.cn (J.Z.)

* Correspondence: fengchunhua@hpu.edu.cn; Tel.: +86-152-2588-7835

Abstract: Recycled aggregate is aggregate prepared from construction waste. With the development of a global economy and people's attention to sustainable development, recycled aggregate has shown advantages in replacing natural aggregate in the production of concrete due to its environmental friendliness, low energy consumption, and low cost. Recycled aggregate exhibits high water absorption and a multi-interface transition zone, which limits its application scope. Researchers have used various methods to improve the properties of recycled aggregate, such as microbially induced calcium carbonate precipitation (MICP) technology. In this paper, the results of recent studies on the reinforcement of recycled aggregate by MICP technology are synthesized, and the factors affecting the strengthening effect of recycled aggregate are reviewed. Moreover, the strengthening mechanism, advantages and disadvantages of MICP technology are summarized. After the modified treatment, the aggregate performance is significantly improved. Regardless of whether the aggregate was used in mortar or concrete, the mechanical properties of the specimens were clearly improved. However, there are some issues regarding the application of MICP technology, such as the use of an expensive culture medium, a long modification cycle, and untargeted mineralization deposition. These difficulties need to be overcome in the future for the industrialization of regenerated aggregate materials via MICP technology.

Keywords: recycled aggregate; biomineralization; sustainability; reinforcement; recycled concrete

\section{Introduction}

Since the beginning of the 21st century, with the continuous prosperity of global construction, a large amount of natural building materials has been consumed to construct tall buildings and dense transportation networks. During the past two decades, billions of tons of construction waste have been produced in China, and related statistics show that construction waste accounts for approximately 4 out of 10 urban waste products [1]. In Shenzhen, one of the most developed cities in China, approximately $84 \%$ of construction waste has been buried in landfills in recent years [2]. From the perspective of sustainable development, it has great significance to recycle materials in construction waste, which is beneficial for alleviating the shortage of natural construction materials together with the land resources for landfill waste.

The aggregate obtained from the crushing and grading of the building solid waste is called recycled aggregate. The concrete prepared by replacing natural aggregate with recycled aggregate in a certain proportion is called recycled concrete. Many studies have shown that employing recycled aggregate will lead to the degradation of the mechanical properties and durability of recycled concrete [3-5]. When recycled aggregate replaces all natural aggregates, the splitting tensile strength, elastic modulus and compressive 
strength of recycled concrete will be greatly reduced [6-8], Guohui [9] found that when the water-cement ratio was 0.44 and the replacement rate of recycled aggregate was $100 \%$, the strength of recycled concrete decreased by nearly $32 \%$ compared with that of natural concrete, which was similar to Xuan's research results [10]. Meanwhile, the chlorine ion diffusion coefficient, carbonization depth and water absorption are all higher than those of natural concrete [11], which indicates that the recycled aggregate has a negative impact on the durability of the recycled concrete. Adessina et al. [12] proposed that there are two main reasons for the degradation of the mechanical properties of recycled concrete, including numerous interface transition zone (ITZs) and old mortar adhering to the aggregate surface. Different from natural aggregate materials, a large amount of adhesive mortar is usually adhered on the recycled aggregate surface, which leads to high water absorption and poor durability of the recycled concrete. Moreover, a more complex ITZ between the fresh mortar and the recycled aggregate was generated in the recycled concrete, as shown in Figure 1 [13].

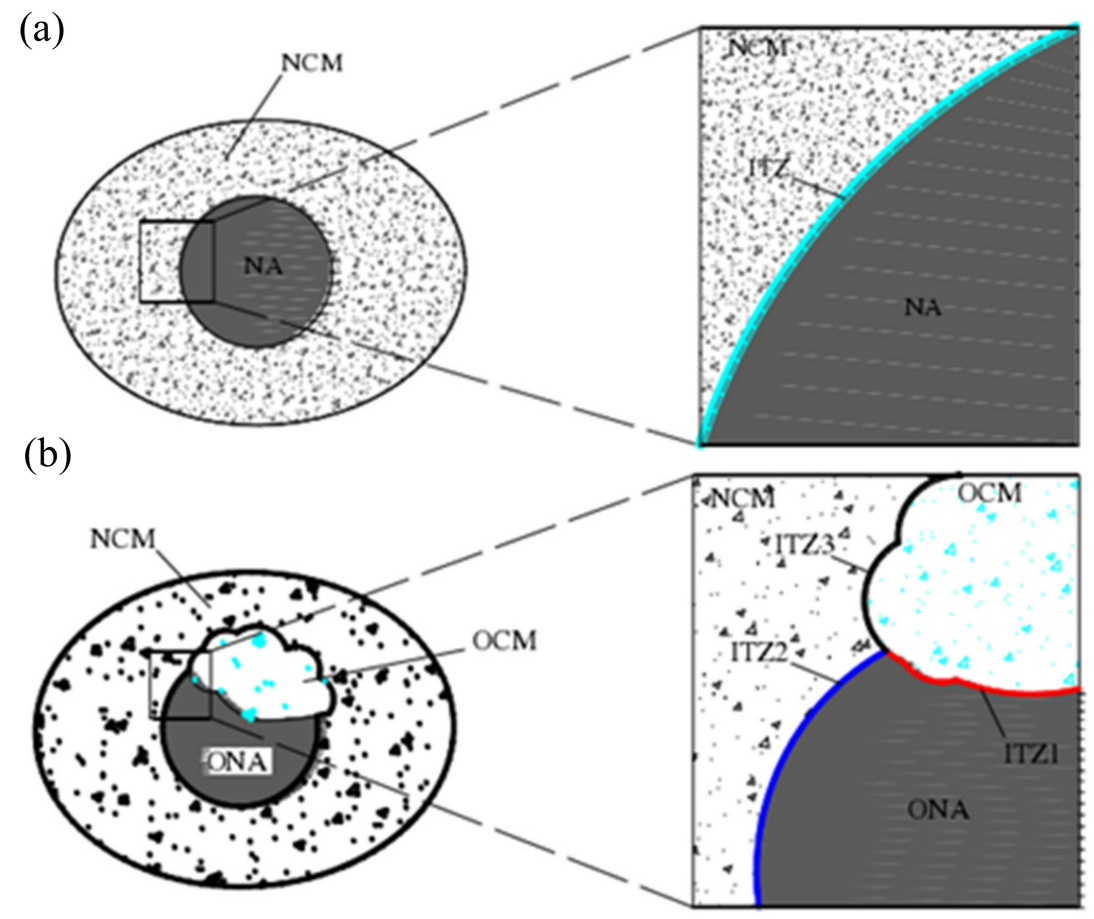

Figure 1. Concrete interface structure [13]: (a) ordinary concrete; (b) recycled concrete; (NA: natural aggregate, ONA: old natural aggregate, NCM: natural concrete mortar, OCM: old concrete mortar, ITZ: interface transition zone).

Compared with natural concrete, recycled concrete has larger porosity, more complex structure and lower apparent density, which leads to the poor mechanical properties and durability of the concrete, limiting its utilization rate. Therefore, to achieve the purpose of recycling recycled aggregate, it is necessary to strengthen and modify the material to improve its performance.

At present, the relatively mature and widely used strengthening technologies of recycled aggregate belong to physical strengthening technology and chemical modification technology. Among them, physical methods strengthen recycled aggregate through a physical process to reduce the water absorption and ITZs by removing the mortar attached to the surface, modifying the particle shape, etc. Commonly used methods include mechanical grinding, particle shaping, heat treatment, and high-pressure pulses [14-17]. Alternatively, chemical methods remove or strengthen the attached mortar on the surface of recycled aggregate through chemical reactions to reduce the water absorption of the aggregate and strengthen the ITZs to improve the mechanical properties and the durability of the aggregate. Common 
methods including cement slurry treatment, polymer impregnation, carbonization curing, chemical reagent pre-preg [18-21]. Relevant studies have shown that the above modification methods have problems such as high energy consumption, large equipment wear and tear, complex processes, long time consumption, and secondary pollution to the environment. In recent years, researchers have found that microbially induced calcium carbonate precipitation (MICP), as a basic geochemical cycle process, is eco-friendly, exhibits low energy consumption and low-cost characteristics [22]. If this technology is used as a means to facilitate recycled aggregate, it will have good development prospects.

This paper comprehensively analyzes the research progress of MICP reinforcement technology in recycled aggregate and discusses the influencing factors, strengthening mechanism, strengthening effect, advantages and disadvantages. Some problems and shortcomings existing in current MICP technology are proposed to provide a reference for relevant researchers.

\section{Microbially Induced Calcium Carbonate Precipitation (MICP) Technology}

Some microorganisms can form mineral precipitates in the Earth's circulation system through a series of physiological activities (respiration, metabolism, reproduction, catalysis, etc.), which is a widely existing complex phenomenon [23]. MICP technology refers to bacterial metabolism producing $\mathrm{CO}_{3}{ }^{2-}$, which then reacts with $\mathrm{Ca}^{2+}$ in soil and concrete to generate $\mathrm{CaCO}_{3}$ precipitates, filling cracks and pores on the surface of soil and buildings to achieve reinforcement. Due to the good adhesion and stability of the resultant $\mathrm{CaCO}_{3}$ crystals and excellent compatibility with cement pastes, MICP technology has been widely applied in the fields of solidifying sand soil to reduce soil permeability [24,25], preventing building settlement [26], repairing and reinforcing concrete cracks [27], and repairing historic buildings [28]. There are three different mechanisms of biomineralized precipitation [29]: Curing the soil, preventing building settlement and slope reinforcement, reducing soil permeability, repairing and reinforcing, and renovating historical buildings in areas such as cracks in concrete have been applied.

Research indicates that there are three different deposition biomineralization mechanisms [22].

1. Bioactivity controlled calcium carbonate precipitate-the process of mineralization and precipitation is directly controlled by cell activities. Mineral precipitates are synthesized in cells or at designated locations on cells. The whole process of the nucleation and growth of mineralized products is greatly dependent on biological activities and requires intense mineralization conditions, so it can only be carried out under specific conditions [30,31];

2. Biological metabolic control calcium carbonate precipitate-the process of mineralization precipitation is influenced by cell activities. Biological metabolic reactions related to biofilms cause the accumulation of organic substances or extracellular polymers on the cell surface, leading to the precipitation of calcium carbonate [31];

3. Biologically induced calcium carbonate precipitate-mineralization precipitation is induced by cell activities. The metabolic activities of microorganisms cause changes in the surrounding chemical environment. Metal ions are attracted by the negatively charged $\mathrm{CO}_{3}{ }^{2-}$ generated by respiration on the cell wall surface, which promotes mineral precipitation on the cell wall surface [31,32].

Adherent mortar and microcracks are the reasons for the poor mechanical properties of the recycled aggregate in mortar or concrete. At present, three ways of strengthening recycled aggregate with MICP technology are usually adopted: (1) Direct immersion: the recycled aggregate is directly soaked in nutrient solution containing the appropriate concentration of bacteria for 7-14 days; (2) Two-stage immersion: first, the bacterial liquid cultured under specific conditions is attached to the regenerated aggregate, and then the regenerated aggregate is immersed in the nutrient solution; (3) Spraying: After the bacterial liquid cultured under specific conditions is attached to the recycled aggregate, nutrient solution is sprayed on surface of the aggregate at a regular and quantitative time. 
Among them, immersion reinforcement is more widely used. Figure 2, as a schematic diagram, depicts the reinforcement of the recycled aggregate employing MICP technology. Owing to the good fill and cementing effect of biomineralized precipitation on adhered mortar and microcracks, as well as the good compatibility with cement-based materials, this technology has potential for intensified use of recycled aggregates [33]. Dick et al. [34] obtained a layer of dense calcium carbonate crystals created by MICP on degraded limestone by carrying out Bacillus ureolytic-driven calcium carbonate precipitation. Their experiments showed that the layer of dense calcium carbonate crystals could effectively reduce the water absorption of limestone. Muynck et al. [35] used bacteria with the number B. SphaericusLMG 22,557 to conduct surface treatment on mortar samples and found that the permeability of samples decreased after biodeposition treatment, and the resistance to carbonation, chloride migration and freeze-thaw increased. The above studies show that the modification treatment has a positive effect on both the performance improvement of limestone (aggregate) and the performance of mortar (adhesive mortar), especially on decreasing water absorption. These experiments show that MICP technology may have a positive effect on intensified recycled aggregates, but the specific strengthening process is affected by the interaction of multiple factors.

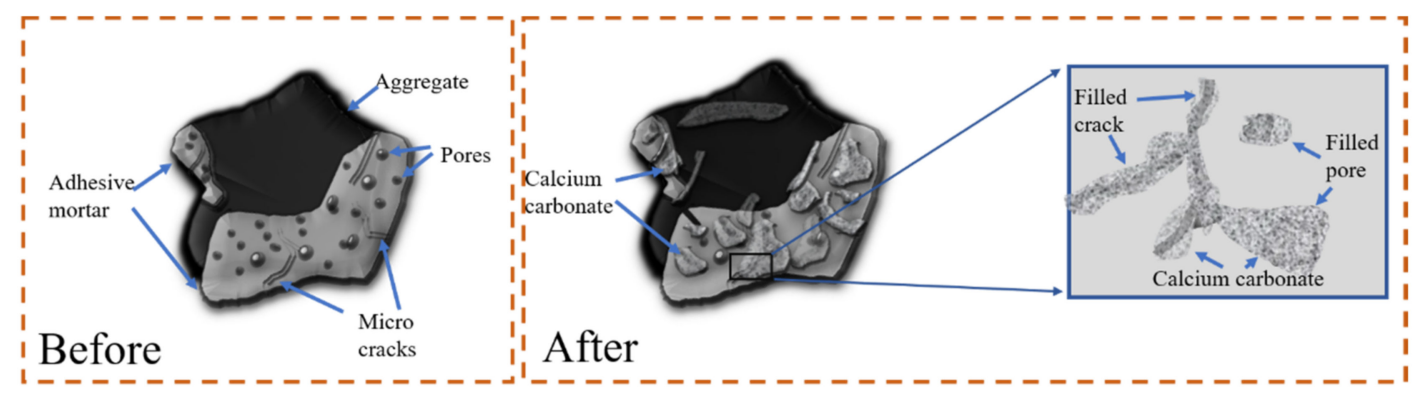

Figure 2. Recycled aggregate enhanced by biodeposition of calcium carbonate.

\section{Factors Influencing the Mineralized Sedimentation}

The mineralization and precipitation induced by microorganisms is a complex process. A number of factors, such as the type of bacteria, calcium source, medium, $\mathrm{pH}$ value, nucleation center location and temperature, and other factors interact together to determine the effect of mineralization precipitation [36,37]. In the following, several important factors affecting the effect of mineralization and deposition are discussed, the modification conditions of recycled aggregate are comprehensively analyzed, and the effect of each influencing factor on the modification of recycled aggregate is discussed.

\subsection{Bacteria}

Bacteria are ubiquitous in every corner of the planet and make up the majority of the planet's biomass. Bacteria come in a variety of shapes, such as spherical, rod-shaped, and helical shapes. Bacterial cells are approximately one-tenth the size of eukaryotic cells and are usually $0.5-5.0 \mu \mathrm{m}$ in length [35]. Studies have shown that many bacteria can produce mineralized deposition of calcium carbonate, but not all strains can produce a good strengthening effect on aggregates, depending on whether the strains have a strong negative potential [34]. The negative potential of the cell surface electrical layer is an important factor for bacteria to efficiently adhere to the surface of aggregate. The positive potential of limestone on the surface of recycled aggregate is similar, which makes bacteria with a high negative potential more likely to get more calcium carbonate to settle down on the surface [38]. Comparing the negative potential of the electrical layer on the surface of different species is helpful for mineralization deposition to occur more effectively.

Ureolytic bacteria are widely used in the field of MICP technology. In the reinforcement process, the urease produced by ureolytic bacteria hydrolyzes urea and produces $\mathrm{CO}_{3}{ }^{2-}$, which generates calcium carbonate precipitates with good cementing ability in an 
environment rich in $\mathrm{Ca}^{2+}$ to repair and fill the surface defects of recycled aggregate and improve its performance [37]. The urease generation rate has an important effect on the rate of calcium carbonate precipitation. Generally, the bacterial concentration determines the rate of bacteria producing urease. The current study results suggest that most of the concentration of bacteria is scheduled for $10^{7}-10^{8}$ cells $/ \mathrm{mL}$, which may be based on the calcium carbonate precipitation rate and the interaction of the urease hydrolysis rate of urea to consider $[39,40]$.

\subsection{Calcium Sources}

The precipitation of calcium carbonate by biomineralization is mainly three crystal types: calcite, vaterite and aragonite. Among these three crystal types, calcite is the best repair material for recycled aggregate, and the stability of vaterite and aragonite is poor compared with that of calcite. In fact, the type of calcium source influences the mineralization rate of MICP. Therefore, the selection of an appropriate calcium source plays a key role in the modification effect of recycled aggregate. Zhan et al. [41] used calcium nitrate and calcium chloride to explore the role of different calcium sources in the study of modified recycled aggregates. The experimental results showed that the weight gain rate treated with calcium nitrate was $2.15 \%$, while the weight gain rate treated with calcium chloride reached 3.1\%. In addition, the data showed that the redesigned aggregate with calcium chloride as the calcium source had the lowest water absorption (1.12) and the highest compressive strength ratio (0.99). These results confirmed that when microorganisms modify aggregates, using calcium chloride as the calcium source could obtain a better strengthening effect than calcium nitrate as the calcium source. Achal et al. [42] further explored the influence of different calcium sources (calcium chloride, calcium oxide, calcium nitrate and calcium acetate) on the mineralization precipitation effect of Bacillus. These researchers found little difference in the colony-forming units between the cultures when mineralization experiments were carried out on media that only differed from one another in the source of calcium, but the maximum growth rate of colonies was observed when calcium chloride was used as the calcium source medium. In contrast, the use of calcium oxide as the calcium source medium colony growth condition was not ideal. Urease is an important enzyme leading to calcium carbonate precipitation in microorganisms, and the yield of urease determines the amount of calcium carbonate precipitation when other conditions are almost unchanged. Different calcium sources also showed different effects on urease production by the same bacteria. In a medium with calcium chloride as the calcium source, Bacillus spp. CR2 showed the highest urease yield. When the calcium source was calcium nitrate, the urease yield produced by bacteria was second only to calcium chloride. When calcium oxide was the calcium source, the amount of urease produced by bacteria was the lowest. In addition, although most of the precipitates were calcite, when different kinds of calcium sources were used by bacteria for mineralization and precipitation, there was the largest amount of calcite in the medium containing calcium chloride. Therefore, calcium chloride might be the most suitable calcium source for bacterial mineralization and precipitation, which was consistent with previous studies [43].

\subsection{Composition of the Culture Medium}

Since the culture medium provides nutrients for the process of microbial-induced mineralization and precipitation, the composition and concentration of the medium have an important effect on the rate of microbial metabolism. Muynck et al. [44] took calcium chloride as the calcium source and soaked the specimens in different nutrient solutions for six days to explore the influence of nutrient broth (a complex nutrient that supports rapid bacterial growth) added to the medium on the morphology of calcium carbonate crystals on the surface of mortar. As shown in Figure 3, SEM observation of the mortar surface showed that in the presence of nutrient broth, calcite crystals were almost absent and granular vaterite particles appeared. This observation indicated that medium composition had a 
profound influence on the crystal morphology of calcite, which could be attributed to the different actual urease levels under different culture conditions. In fact, a specific medium composition and concentration may directly control the size and form of calcium carbonate generated [44]. Precisely controlling the precipitation process is extremely beneficial for obtaining a better recycled aggregate strengthening effect.
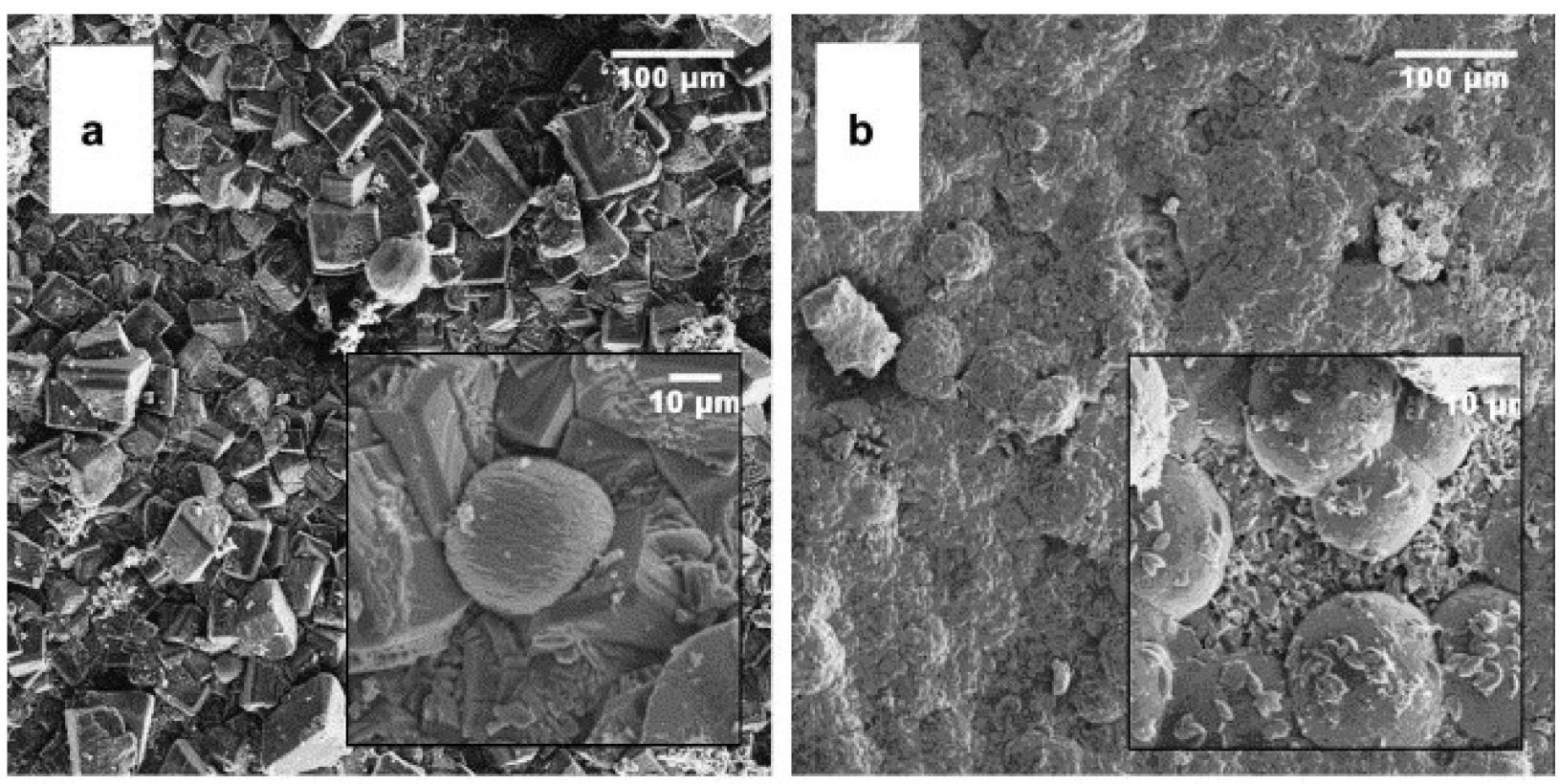

Figure 3. Calcium carbonate crystal morphology on the mortar surface [44]: (a) calcium chloride; (b) calcium chloride and nutrient broth. Reprinted from Construction and Building Materials, Bacterial carbonate precipitation as an alternative surface treatment for concrete, Willem De Muynck, Kathelijn Cox, Nele De Belie, Willy Verstraete, 2008, 22, 875-885, with permission from Elsevier.

In the process of recycled aggregate enhancement by microorganisms, standard media usually include a nutrient broth culture medium and yeast extract [45]. To obtain a better precipitation effect or economic value, researchers propose partially replacing the composition of the culture medium.

To reduce the cost of culture medium, researchers have focused on waste containing rich nutrients such as chicken manure wastewater, corn milk, lactose mother liquor and activated sludge from the agriculture, dairy and baking industries [46]. Grabiec et al. [40] chose two kinds of media to culture bacteria in the process of exploring microbe-induced carbonate precipitation: one was a standard medium containing a meat extract and peptone, and the other was a whey medium. The results showed that the bacterial concentration reached $9.0 \times 10^{6} \mathrm{CFU} \mathrm{mL} \mathrm{mL}^{-1}$ after $48 \mathrm{~h}$ of culture in the standard medium, and the highest bacterial concentration reached $3.7 \times 10^{5} \mathrm{CFU} \mathrm{mL}^{-1}$ after $48 \mathrm{~h}$ of culture in the whey medium, which suggested that whey could be a promising alternative medium for Pasteuria. Achal et al. [45] cultured Pasteurella in three different media (lactose mother medium, nutrient medium, yeast extract medium) for $30 \mathrm{~h}$ and further explored the feasibility of lactose mother liquor as an alternative nutrient source for Pasteurella in intensified recycled aggregate concrete using the MICP technique. These authors found that the growth status of bacteria in different media was similar, and there was no significant difference in bacterial concentration. Then, they tested the urease activity of three kinds of culture media, and the results showed that although the lactose mother liquid medium was slightly inferior to the other two kinds of culture media, the effects of the three kinds of calcium carbonate precipitation and urease activity in the medium change curve were similar. These results provide reliable evidence for the use of lactose mother liquor instead of standard medium in bacterial culture. 
The cost of lab-grade bacterial culture media could reach $60 \%$ of the total cost in the process of using MICP technology to enhance recycled aggregate [46]. It is obvious that a standard medium with a high cost can have a good effect on the process of MICP, but the high cost of this technique makes it a considerable challenge to apply in the field of engineering. This issue should be mitigated to find suitable substitutes for nutrients to reduce the economic cost of media for the industrialization of mineralized precipitation technology.

\subsection{Effect of $p H$}

The $\mathrm{pH}$ of the environment has an important influence on the process of MICP. In the natural world, a variety of microorganisms can create an alkaline environment for the formation of calcium carbonate through various physiological activities, such as photosynthesis, urinase, ammonification, denitrification, sulfate reduction, anaerobic sulfide oxidation and methane oxidation [47]. A study showed that $\mathrm{pH}$ has a double effect on calcium carbonate precipitation. Taking Pasteurella as an example, the most suitable growth $\mathrm{pH}$ was approximately 9.5. The specific urease activity of Pasteurella increased with increasing $\mathrm{pH}$, and the urease activity reached the peak value when the $\mathrm{pH}$ was approximately 8 , but the precipitation amount of calcium carbonate only reached the maximum value when the $\mathrm{pH}$ value was 9.5 under the combined action of a high specific urease activity and bacterial number [45]. The optimum $\mathrm{pH}$ for mineralization and precipitation is slightly different with various microorganisms because the process needs to occur under alkaline conditions. However, after the $\mathrm{pH}$ reaches its peak value of 9.5, the amount of calcium carbonate precipitation decreases sharply as the $\mathrm{pH}$ value increases. Qiu et al. [48] explored the influence of $\mathrm{pH}$ on the process of MICP. The experimental results indicated that the amount of calcium carbonate precipitation showed a tendency to rise and then fall as the $\mathrm{pH}$ of the medium increased. When the $\mathrm{pH}=7$, the amount of calcium carbonate precipitation in the medium was only $0.016 \mathrm{~g}$, and when the $\mathrm{pH}$ of the medium rose to 9 , the mass of calcium carbonate precipitation reached a peak of $0.111 \mathrm{~g}$, which was about 10 times the mass of $\mathrm{pH}=7$. After that, with the rise of $\mathrm{pH}$, the amount of calcium carbonate precipitation decreased. When $\mathrm{pH}=10.5$, the mass of precipitation was $0.050 \mathrm{~g}$.

The cement provides an alkaline environment for the growth of bacteria, which is conducive to the formation of calcium carbonate precipitation during the reinforcement of the recycled aggregate. In the current research on the enhancement of recycled aggregate by MICP technology, most researchers left the nutrient solution $\mathrm{pH}$ in the optimum range of bacterial metabolism. Zeng et al. [49] cultivated S. pasteurii DSM 33 strains with hydrochloric acid and sodium hydroxide to adjust the medium $\mathrm{pH}$ value to 9.5. Xu et al. [50] chose to adjust the $\mathrm{pH}$ of the medium to 7.0 when using the same bacteria from different sources in the experiment.

\subsection{Availability of the Nucleation Center}

Nucleation center effectiveness for the continuous stability of calcium carbonate formation is very important. There are three different mechanisms of biomineralization precipitation, as illustrated above. The mechanism type of bioactivity controlling calcium carbonate precipitate is highly dependent on the cell metabolism and precipitation process, which makes the mineralization and deposition process take a long time. However, because strengthening the aggregate requires substantial calcium carbonate precipitation, this mechanism is not suitably used for modifying recycled aggregate. The latter two mechanisms (biological metabolic control calcium carbonate precipitate and biologically induced calcium carbonate precipitate) can provide a more controllable precipitation process, so the MICP technique usually chooses biologically metabolic and biologically induced strains to induce mineralizing precipitation [32,51].

Critical saturation is the state in which the maximum amount of precipitation is induced by microorganisms under a given condition. The enhancement of recycled aggregate using MICP technology requires a series of delicate operations. In this process, 
the nucleation center affects the state and degree of nucleation, and the saturation state greatly affects the reinforcement effectiveness. Electron acceptor is the essence of nucleation centers. Tobler et al. [52] proposed that electron acceptors, such as oxygen in Pasteurella, play an important role in microbial-induced mineralization precipitation. Taking ureolytic bacteria as an example, although ureolytic activity is not dependent on oxygen, the growth of microorganisms and urease activity are limited by the availability of electron acceptors. To confirm the influence of oxygen on the aggregate modification effect when MICP technology was used to strengthen the recycled aggregate, Zhu Yaguang [53] selected different oxygen supply concentrations and soaking positions to modify the recycled aggregate. The experimental results showed that when the concentration of calcium peroxide was $15 \mathrm{~g} / \mathrm{L}$ and the soaking position was in the middle of the culture medium, the water absorption rate of recycled aggregate decreased by $40.4 \%$, the crushing index decreased by $19.7 \%$, and the porosity was significantly improved. A large number of calcium carbonate crystals filled the cracks of aggregate, and the modification effect of aggregate was significantly improved. The urease activity may be limited by the existing enzymes in the inoculation of the aerobic culture. To overcome the problem of insufficient urease activity during mineralization precipitation induced by microorganisms, native populations can be stimulated by the injection of a growth medium rich in electron acceptors or urease to make mineralization occur efficiently and continuously [54].

Mineralization precipitation is a passive process that protects cells from harmful calcium concentrations for a short period of time, in which microorganisms are spontaneously involved [55]. It has been reported that almost all bacteria can induce the precipitation of calcium carbonate [56]. However, the requirement of mineralization precipitation is different for various bacteria. Similarly, the number of electron acceptors provided differs sharply. It is crucial to continue to explore the biological activities of strains in the laboratory to obtain the most effective nucleation centers.

\subsection{Temperature}

Temperature always affects the whole process of biological growth and reproduction. Different bacteria have different degrees of alkali tolerance and different $\mathrm{pH}$ values to achieve the best precipitation effect, but most of the bacteria show similar choices at the appropriate temperature. Kim et al. [57] explored the influence of different temperatures on calcium carbonate deposition in S. saprophyticus. and S. pasteurii. The results showed that the two kinds of bacteria were very sensitive to temperature changes during the precipitation process, but both of them showed the best precipitation amount at $30{ }^{\circ} \mathrm{C}$. The effect of temperature on bacterial activity usually varies from species to species, but the cell activity of most bacteria is limited below $5^{\circ} \mathrm{C}$ [58]. In addition, temperature also has a profound influence on the rate of urease promoting urea hydrolysis. Low temperature will reduce urease activity, while high temperature will deactivate urease. In the range of $5-37^{\circ} \mathrm{C}$, urease activity will increase exponentially with increasing temperature [59]. Under the condition of good cell activity, the process of urease-catalyzed urea hydrolysis is highly dependent on temperature. Suitable temperature can improve the rate of bacterial calcite precipitation and the ability of bacterial strains to form crystals. Keeping the precipitation process occurring at an appropriate temperature is conducive to obtaining a satisfactory treatment effect.

\section{Reinforcement Mechanism}

On the one hand, the mineralization induced by microorganisms is controlled by the metabolism of microorganisms. On the other hand, mineralization follows the physicochemical rule of mineral nucleation. The mechanism of inducing calcium carbonate precipitation by different microorganisms is slightly different. Microorganism species are accustomed to divide into ureolytic bacteria and nonureolytic bacteria according to the metabolic manner. Hereby, the mechanism of microbially strengthening reclaimed aggregate is according to the type of bacteria. 


\subsection{Mineralization Mechanism of Ureolytic Bacteria}

Bacteria have the largest ratio of the surface area to volume in all forms of life and have a negative charge on the cell surface $[60,61]$. The large surface area and negative charge enable the bacterial surface to adsorb dissolved metal ions. Taking Bacillus ureolyticus globules as an example [34,62,63], Bacillus grows in a suitable nutrient solution concentration of urea, and calcium salt produces urease, which catalyzes urea hydrolysis in the nutrient solution, generating carbamic acid ester and ammonia, as illustrated in reaction Equation (1).

Carbamate is unstable and spontaneously hydrolyzes to produce ammonia and carbonic acid $\left(\mathrm{H}_{2} \mathrm{CO}_{3}\right)$, as shown in Equation (2). The interaction between ammonia and carbonic acid will lead to an increase in the environmental $\mathrm{pH}$ value and form $\mathrm{CO}_{3}{ }^{2-}$. The reactions are shown in Equations (3)-(5).

$$
\begin{gathered}
\mathrm{CO}\left(\mathrm{NH}_{2}\right)_{2}+\mathrm{H}_{2} \mathrm{O} \rightarrow \mathrm{NH}_{2} \mathrm{COOH}+\mathrm{NH}_{3} \\
\mathrm{NH}_{2} \mathrm{COOH}+\mathrm{H}_{2} \mathrm{O} \rightarrow \mathrm{NH}_{3}+\mathrm{H}_{2} \mathrm{CO}_{3} \\
\mathrm{H}_{2} \mathrm{CO}_{3} \rightleftarrows \mathrm{HCO}_{3}^{-}+\mathrm{H}^{+} \\
\mathrm{NH}_{3}+\mathrm{H}_{2} \mathrm{O} \rightleftarrows \mathrm{NH}_{4}^{+}+\mathrm{OH}^{-} \\
\mathrm{HCO}_{3}^{-}+\mathrm{H}^{+}+2 \mathrm{NH}_{4}^{+}+2 \mathrm{OH}^{-} \rightleftarrows \mathrm{CO}_{3}^{2-}+2 \mathrm{NH}_{4}^{+}+2 \mathrm{H}_{2} \mathrm{O}
\end{gathered}
$$

The negative charge carried by the cell wall of Bacillus spontaneously adsorbs $\mathrm{Ca}^{2+}$ in the nutrient solution. Finally, the generated carbonate and calcium ions form calcium carbonate precipitates on the cell wall, which serve as nucleation sites. The reaction is shown in Equations (6) and (7).

$$
\begin{gathered}
\mathrm{Ca}^{2+}+\text { Cell } \rightarrow \text { Cell-Ca }{ }^{2+} \\
\text { Cell- } \mathrm{Ca}^{2+}+\mathrm{CO}_{3}{ }^{2-} \rightarrow \text { Cell-CaCO } \\
\end{gathered}
$$

The process of formation of calcium carbonate crystals by bacterial mineralization and precipitation on the cell wall is depicted in Figure 4 [64].
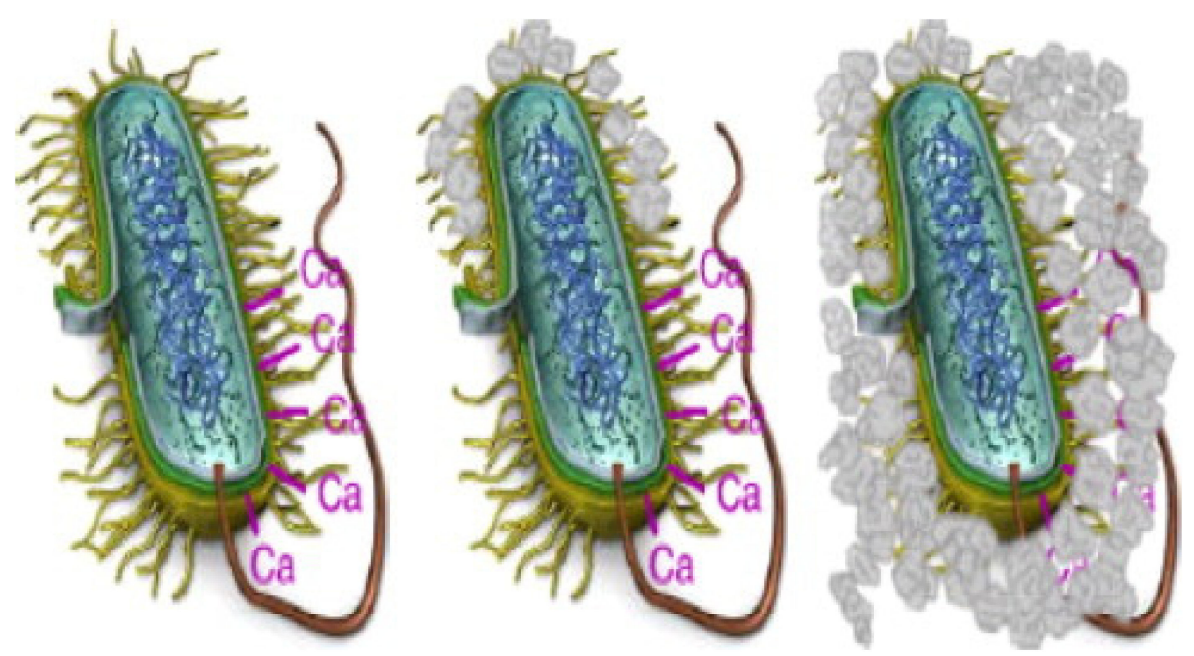

Figure 4. Process of formation of calcium carbonate by bacteria on cell wall [64]. Reprinted from Construction and Building Materials, Effect of ureolytic bacteria on concrete properties, Rafat Siddique, Navneet Kaur Chahal, 2011, 25, 3791-3801, with permission from Elsevier.

The water absorption rate and weight gain directly show the effect of mineralized precipitation. The precipitated particles fully cover the surface area of the aggregate and filling the surface pores will reduce water absorption. Wang et al. [65] used Bacillus sphaer- 
icus LMG22257 and different soaking methods to strengthen the aggregate (a-no soaking treatment; $\mathrm{b}$ - one basic soaking treatment; $\mathrm{c}$ - two basic soaking treatments). The results showed that the surface of the aggregate after two soaking treatments was completely covered by dense particles, which were a spherical aragonite type and a hexagonal calcite type of calcium carbonate. In addition, bacterial imprints could be clearly seen on the particles, which indicated that the production of precipitation depended on the physiological activities of bacteria.

Ureolytic bacteria, as a way to strengthen recycled aggregates, have attracted the attention of many researchers due to their advantages of simplicity, high efficiency and low energy consumption. However, ureolytic bacteria will release the unwanted byproduct $\mathrm{NH}_{4}{ }^{+}$in the process of urea decomposition, and $\mathrm{NH}_{4}{ }^{+}$salts and their conversion products may cause problems such as water contamination, aggregate discoloration, or metabolic competition among bacterial communities [32,66].

\subsection{Mineralization Mechanism of Nonureolytic Bacteria}

To avoid the generation of $\mathrm{NH}_{3}$ in the process of mineralization, some researchers proposed using nonureolytic bacteria to induce the mineralization precipitation of $\mathrm{CaCO}_{3}$ to strengthen the recycled aggregate. Then, the mineralization mechanism of nonureolytic bacteria was introduced.

\subsubsection{Fermentation of Fatty Acids}

Among the nonureolytic bacteria, some bacteria rely on their metabolism to complete the mineralization and precipitation process. After the metabolism of basophilic carbonate mineralizing bacteria, the organic acids in a nutrient solution react with $\mathrm{CO}_{2}$ generated in the metabolic process to form $\mathrm{CaCO}_{3}$ precipitates in an alkaline environment. Notably, different types of organic carbon sources have a significant effect on the type and morphology of the precipitated crystals. Common organic carbon sources include a variety of organic acids such as calcium lactate, calcium acetate, calcium glutamate and sodium gluconate $[67,68]$.

Taking calcium lactate as the calcium source, the mineralization process can be expressed as Equation (8).

$$
\mathrm{CaC}_{6} \mathrm{H}_{10} \mathrm{O}_{6}+5 \mathrm{O}_{2} \rightarrow \mathrm{CaCO}_{3}+4 \mathrm{CO}_{2}+5 \mathrm{H}_{2} \mathrm{O}
$$

Taking calcium glutamate as the calcium source, the mineralization process can be expressed as Equation (9).

$$
\mathrm{CaC}_{10} \mathrm{H}_{10} \mathrm{~N}_{2} \mathrm{O}_{8}+\mathrm{O}_{2} \rightarrow \mathrm{CaCO}_{3}+\mathrm{R}_{\mathrm{x}} \mathrm{NH}_{\mathrm{y}}+\mathrm{CO}_{2}+\mathrm{H}_{2} \mathrm{O}
$$

Among them, $\mathrm{R}_{\mathrm{x}} \mathrm{NH}_{\mathrm{y}}$ is an amine compound.

When calcium lactate is the calcium source, the precipitate is calcite. However, when calcium glutamate is the calcium source, the precipitation produced is mainly vaterite, and there is a small amount of calcite crystals. Xu et al. [68] believed that the existence of a small amount of calcite crystals is caused by the instability of vaterite. Plummer et al. [69] pointed out that among the three main crystal forms of $\mathrm{CaCO}_{3}$ (calcite, vaterite, and aragonite), vaterite is the most unstable crystal. When the temperature is higher than $3^{\circ} \mathrm{C}$, it gradually transforms into more stable calcite or aragonite. Moreover, vaterite has strong solubility and low density, so it is not suitable for filling the porous parts on the surface of recycled aggregate. Qian et al. [70] found that $\mathrm{pH}$ plays an important role in the mineralization process. Equations (10) and (11) indicate that mineralization and precipitation of calcite only begin when the solution is alkaline.

$$
\begin{aligned}
& \mathrm{CO}_{2}+\mathrm{OH}^{-} \rightarrow \mathrm{HCO}_{3}^{-} \\
& \text {Cell- } \mathrm{Ca}^{2+}+\mathrm{HCO}_{3}^{-}+\mathrm{OH}^{-} \rightarrow \text { Cell- }-\mathrm{CaCO}_{3} \downarrow+\mathrm{H}_{2} \mathrm{O}
\end{aligned}
$$


Notably, basophilic carbonate mineralizing bacteria rely on their metabolism for mineralization, and precipitation does not produce $\mathrm{NH}_{3}$ in the process of producing calcium carbonate, but the mineralization process depends on the rate of metabolism. A variety of factors, such as the strain type, medium composition, temperature, $\mathrm{pH}$, and concentration of $\mathrm{O}_{2}$, play a significant role in the metabolic process of bacteria, which makes it harder for the laboratory to control mineralized precipitation.

\subsubsection{Carbonic Anhydrase Catalysis}

Carbonic anhydrase bacteria promote the mineralization precipitation of $\mathrm{CaCO}_{3}$ by its ability to capture $\mathrm{CO}_{2}$. Carbonic anhydrase is a metal enzyme widely found in nature, and its active center has a zinc atom necessary for catalysis. The carbon dioxide hydration reaction is the most important biological function for carbonic anhydrase [71]. During the hydration reaction, $\mathrm{CO}_{2}$ reacts in the activity center of the enzyme. Reactions are shown in Equations (12) and (13) [72]:

$$
\begin{gathered}
\mathrm{E}-\mathrm{Zn}^{2+}+\mathrm{OH}^{-}+\mathrm{CO}_{2} \leftrightarrow \mathrm{E}-\mathrm{Zn}^{2+}+\mathrm{HCO}_{3}^{-} \\
\mathrm{E}-\mathrm{Zn}^{2+}+\mathrm{HCO}_{3}^{-}+\mathrm{H}_{2} \mathrm{O} \leftrightarrow \mathrm{E}-\mathrm{Zn}^{2+}+\mathrm{H}_{2} \mathrm{O}+\mathrm{HCO}_{3}^{-}
\end{gathered}
$$

In fact, the rate constant of the first-order reaction of at $25^{\circ} \mathrm{C}$ is $0.037 \mathrm{~s}^{-1}$ without a catalyst, and the reaction rate can be almost seven orders of magnitude higher after carbonic anhydrase catalysis [73]. The excellent catalytic ability of carbonic anhydrase has attracted the attention of researchers. Qian et al. [74] proposed applying carbonic anhydrase bacteria to achieve the MICP technique and predicted that carbonic anhydrase bacteria could induce and accelerate the precipitation reaction of calcium carbonate in alkaline environments on cement surfaces to achieve protection and repair effects on defective surfaces. The reaction process is shown in Equations (14) and (15):

$$
\begin{gathered}
\mathrm{CO}_{2}+\mathrm{H}_{2} \mathrm{O} \leftrightarrow \mathrm{HCO}_{3}^{-}+\mathrm{H}^{+} \\
\mathrm{Ca}^{2+}+\mathrm{HCO}_{3}^{-}+\mathrm{OH}^{-} \rightarrow \mathrm{CaCO}_{3}+\mathrm{H}_{2} \mathrm{O}
\end{gathered}
$$

Compared with the process of mineralization induced by ureolytic bacteria, using carbonic anhydrase bacteria to mineralize and deposit calcium carbonate to repair recycled aggregates is not only harmless and nontoxic but also absorbs $\mathrm{CO}_{2}$ from the air as the reaction raw material, which is relatively friendly to the environment. On the one hand, the carbonic anhydrase catalytic process is greatly affected by $\mathrm{pH}$, temperature, and $\mathrm{CO}_{2}$ concentration, which limit the mineralization rate. On the other hand, the reversibility of the carbon dioxide hydration reaction leads to the constant generation of $\mathrm{CO}_{2}$ in the whole precipitation process, which increases the porosity of the precipitation products and then affects the performance of recycled concrete in the later stage [75].

\subsubsection{Denitrification}

Biological reduction of $\mathrm{NO}_{3}^{-}$occurs when microorganisms oxidize organic matter. Nitrifying reducing bacteria use $\mathrm{NO}_{3}^{-}$instead of $\mathrm{O}_{2}$ as electron acceptor to produce calcium carbonate precipitation in the nutrient solution. The reaction process is shown in Equations (16)-(20) [76,77].

$$
\begin{aligned}
2 \mathrm{HCOO}^{-}+2 \mathrm{NO}_{3}^{-}+2 \mathrm{H}^{+} & \rightarrow 2 \mathrm{CO}_{2}+2 \mathrm{H}_{2} \mathrm{O}+2 \mathrm{NO}_{2}^{-} \\
\mathrm{HCOO}^{-}+2 \mathrm{NO}_{2}^{-}+3 \mathrm{H}^{+} & \rightarrow \mathrm{CO}_{2}+2 \mathrm{NO}+2 \mathrm{H}_{2} \mathrm{O} \\
\mathrm{HCOO}^{-}+2 \mathrm{NO}_{2}^{-}+3 \mathrm{H}^{+} & \rightarrow \mathrm{CO}_{2}+2 \mathrm{NO}+2 \mathrm{H}_{2} \mathrm{O} \\
\mathrm{HCOO}^{-}+\mathrm{N}_{2} \mathrm{O}+\mathrm{H}^{+} & \rightarrow \mathrm{CO}_{2}+\mathrm{N}_{2}+\mathrm{H}_{2} \mathrm{O} \\
\mathrm{Ca}^{2+}+\mathrm{CO}_{2}+\mathrm{H}_{2} \mathrm{O} & \rightarrow \mathrm{CaCO}_{3}+2 \mathrm{H}^{+}
\end{aligned}
$$


As electron acceptor in most mineralization reactions, $\mathrm{O}_{2}$ plays an important role in the mineralization process. At present, soaking is the main strengthening method for MICP regeneration aggregate, and the poor solubility of $\mathrm{O}_{2}$ in solution limits the number of electron acceptors in solution. Nitrifying reducing bacteria can produce calcium carbonate deposits in anoxic environment, which is undoubtedly a significant advantage for strengthening recycled aggregate [78]. In addition, it can survive in an environment lacking nutrients and produce calcium carbonate deposits, which may also reduce the cost of the aggregate strengthening process.

\subsubsection{Sulphur Cycle}

Mondal et al. [77]. pointed out that, as a non-urealytic bacterium, sulfate reducing bacteria have two ways to mineralize and deposit calcium carbonate.

Sulfate reducing bacteria can reduce sulfate to $\mathrm{H}_{2} \mathrm{~S}$ with the production of $\mathrm{HCO}_{3}{ }^{-}$in an organic-rich and oxygen-free environment. The separation of $\mathrm{H}_{2} \mathrm{~S}$ from the environment will lead to the rise of $\mathrm{pH}$ in the surrounding environment, and the rise of $\mathrm{pH}$ will further promote the generation of calcium carbonate precipitation. The reaction process is shown in Equations (21)-(23) [79].

$$
\begin{gathered}
\mathrm{CaSO}_{4} \cdot 2 \mathrm{H}_{2} \mathrm{O} \rightarrow \mathrm{Ca}^{2+}+\mathrm{SO}_{4}^{2-}+2 \mathrm{H}_{2} \mathrm{O} \\
2\left(\mathrm{CH}_{2} \mathrm{O}\right)+\mathrm{SO}_{4}^{2-} \rightarrow \mathrm{H}_{2} \mathrm{~S}+2 \mathrm{HCO}_{3}^{-}+\mathrm{CO}_{2}+\mathrm{H}_{2} \mathrm{O} \\
\mathrm{Ca}^{2+}+\mathrm{HCO}_{3}^{-} \rightarrow \mathrm{CaCO}_{3}+\mathrm{H}^{+}
\end{gathered}
$$

In addition, there is another mineralization process of sulfate reducing bacteria. Sulfate-reducing bacteria can also reduce calcium sulfate to calcium sulfide. After further reaction of reaction products in aqueous solution, mineralization and deposition of calcium carbonate is completed. The reaction process is shown in Equations (24)-(27) [80].

$$
\begin{gathered}
\mathrm{CaSO}_{4}+2\left(\mathrm{CH}_{2} \mathrm{O}\right) \rightarrow \mathrm{CaS}+2 \mathrm{CO}_{2}+2 \mathrm{H}_{2} \mathrm{O} \\
\mathrm{CaS}+2 \mathrm{H}_{2} \mathrm{O} \rightarrow \mathrm{Ca}(\mathrm{OH})_{2}+\mathrm{H}_{2} \mathrm{~S} \\
\mathrm{CO}_{2}+\mathrm{H}_{2} \mathrm{O} \rightarrow \mathrm{H}_{2} \mathrm{CO}_{3} \\
\mathrm{Ca}(\mathrm{OH})_{2}+\mathrm{H}_{2} \mathrm{CO}_{3} \rightarrow \mathrm{CaCO}_{3}+2 \mathrm{H}_{2} \mathrm{O}
\end{gathered}
$$

Similar to nitrate reducing bacteria, sulfate reducing bacteria also do not rely on $\mathrm{O}_{2}$ as an electron acceptor. However, a difficult problem to solve is that sulfate reducing bacteria release $\mathrm{H}_{2} \mathrm{~S}$ gas during mineralization, which is not environmentally friendly. In addition, the mineralization process needs to be carried out under the conditions of rich nutrients, and the $\mathrm{pH}$ will constantly change, which is not conducive to the uniform and stable production of calcium carbonate.

\section{Reinforcement Effect of Recycled Aggregate}

Researchers are most concerned with whether the performance of recycled aggregate and recycled aggregate concrete (mortar) can be improved regardless of how the aggregate is strengthened. Singh et al. [81] discussed the strengthening effect of reclaimed aggregate in detail. These investigators studied the modification effect of recycled aggregate by ureolytic bacteria, nonureolytic bacteria and nanomaterials. They point out that the optimal strengthening period of recycled aggregate was 14 days. After 14 days of modification treatment, the increase in specific gravity was found to be $29 \%$ and $30 \%$ as well as the percentage decrease in water absorption was found to be $42.9 \%$ and $64.3 \%$ in Non-Ureolytic (B. cohnii) and Ureolytic bacteria (B. megaterium) modified recycled aggregate, respectively. Both biological and bio-nanocomposite strengthening had obvious strengthening effects on the ITZ of the recycled aggregate. Figures 5 and 6 show the ITZ of natural aggregate concrete and the ITZ of recycled aggregate concrete after modification, respectively. 

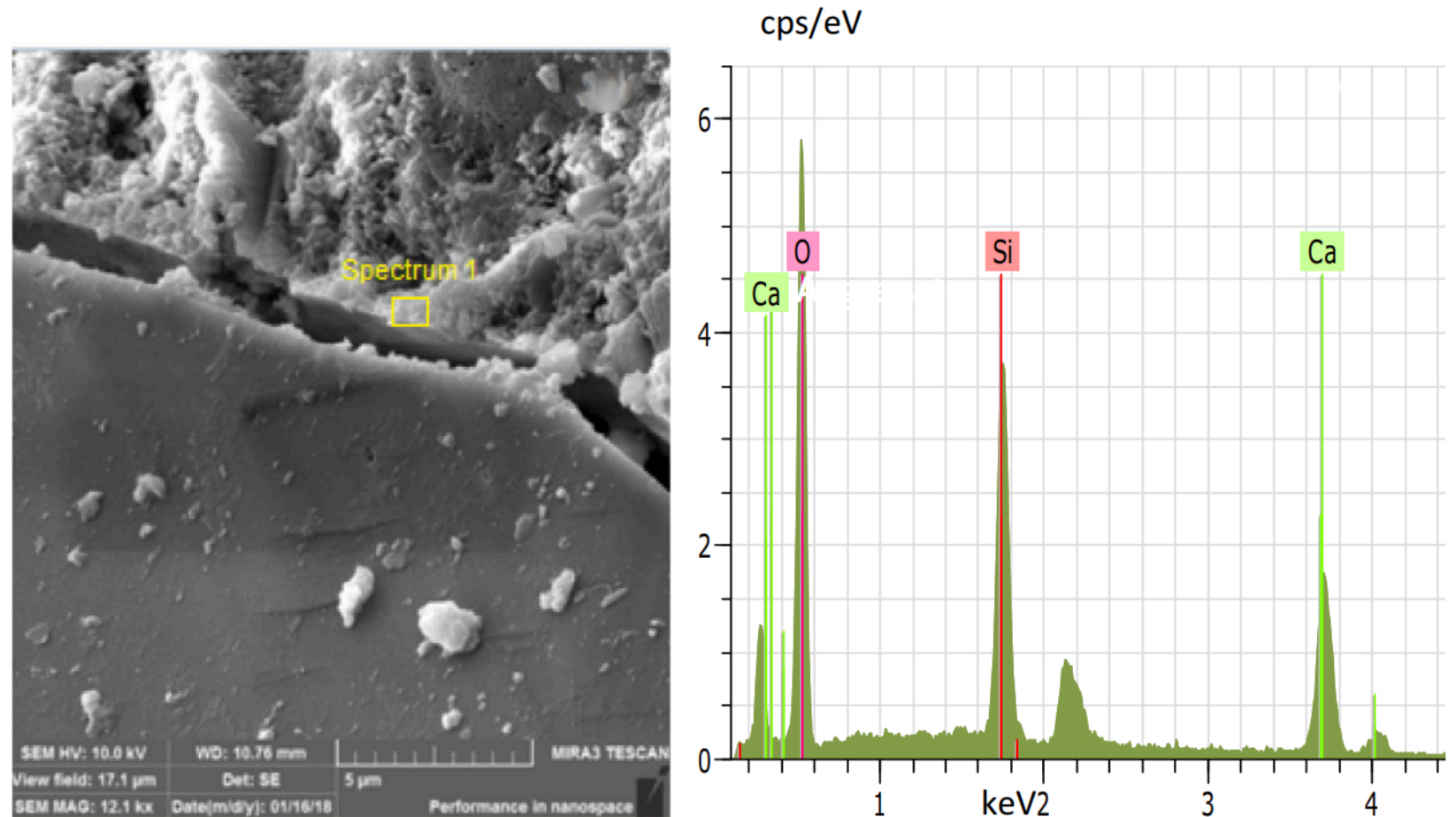

Figure 5. Microstructure diagram of interface transition zone of natural aggregate concrete [81]. Reprinted from Construction and Building Materials, Studies on performance enhancement of recycled aggregate by incorporating bio and nano materials, L.P. Singh, Vishakha Bisht, M.S. Aswathy, Leena Chaurasia, Sanjay Gupta, 2018, 181, 217-226, with permission from Elsevier.
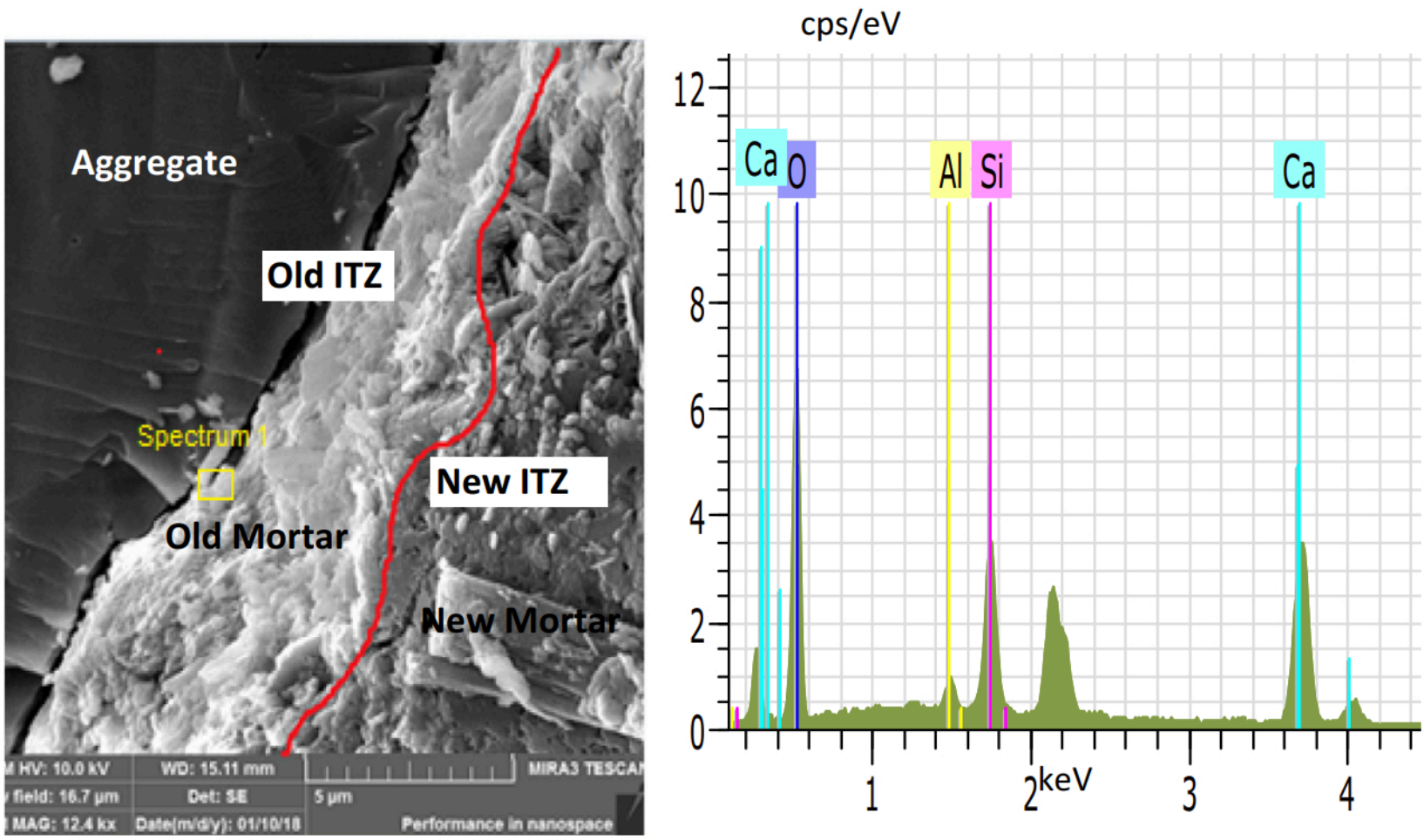

Figure 6. Microstructure diagram of interfacial transition zone of recycled aggregate concrete [81]. Reprinted from Construction and Building Materials, Studies on performance enhancement of recycled aggregate by incorporating bio and nano materials, L.P. Singh, Vishakha Bisht, M.S. Aswathy, Leena Chaurasia, Sanjay Gupta, 2018, 181, 217-226, with permission from Elsevier. 
It can be seen from the figures that natural aggregate concrete had an ITZ with a width of $580 \mathrm{~nm}$, while the transition zone between the recycled concrete aggregate and used mortar was only $170 \mathrm{~nm}$. Energy dispersive X-ray spectrometry (EDX) also showed that the content of calcium and silicon was increased, which confirmed that the microstructure of the reinforced aggregate was denser.

A large amount of recycled fine aggregate can be produced in the process of recycling recycled aggregate. To date, most physical or chemical strengthening treatment methods for recycled fine aggregates have not obtained optimistic results. When adding microorganisms to modify recycled aggregates, the experimental data on the enhancement of regenerated aggregate by MICP technology may be optimistic. Take the research results of Xu et al. [82] as an example, When they explored the effect of microbial mineralization deposition on the regenerated fine aggregate, they found that compared with the control group, the compressive strength and flexural strength of recycled mortar made of recycled fine aggregate treated by microorganisms were generally improved. The 28 days compressive strength and flexural strength of the recycled mortar specimen increased by $27.78 \%$ and $34.59 \%$, respectively. The nanoindentation results show that the elastic modulus and microhardness of the interfacial transition zone can be increased by more than $100 \%$. These studies indicated that the MICP technique also has great potential for enhancing reclaimed fine aggregates.

Zeng et al. [49] studied the influence of microbially induced carbonate precipitation on the performance of recycled aggregate concrete and modified the concrete model by using different calcium source addition methods and rotating treatment methods. These coworkers suggested that regenerated aggregates with better performance can be obtained by soaking them in bacteria, modifying them in a sterile medium, and then adding calcium ions in batches. When the modified aggregate was used in concrete, the compressive strength of the modified aggregate concrete was increased by $6.3 \%$ compared with that of the unmodified aggregate concrete. The results of the microhardness test in the ITZ showed the reason for the improvement in mechanical properties. For recycled aggregate concrete without modification, the microhardness of the new and old transition zones is similar, but for recycled aggregate concrete after modification, the microhardness of the new ITZ is approximately $16.5 \%$ higher than that of the old ITZ. This increase indicated that the mineralized precipitation of microorganisms could provide a more favorable binding force between the reclaimed aggregate and cement-based materials. Xu et al. [50] tested the durability of modified concrete when exploring the coupling effect of carbonation and bioprecipitation in concrete surface treatment. These authors found that the resistance to chloride ion penetration of MICP-modified concrete increased by $6.2 \%$, while carbonization followed by the MICP technique increased the resistance to chloride ion penetration by $10.5 \%$. Muynck et al. [44] believed the reason for the improved ability to resist chloride ion penetration was that on the one hand, the density of the aggregate surface precipitation of calcium carbonate crystals could effectively reduce the capillary water absorption rate and gas permeation. On the other hand, irregular calcium carbonate crystals covering the aggregate surface could improve the bonding force between the aggregate and cement based materials. Therefore, the performance of recycled concrete could be improved.

To intuitively describe the modification effect of the MICP technique on recycled aggregate, Table 1 compares several cases of recycled aggregate before and after strengthening: 
Table 1. Effect of reinforcement treatment on properties of reclaimed aggregate.

\begin{tabular}{|c|c|c|c|c|c|c|c|c|c|c|c|}
\hline \multirow{4}{*}{$\begin{array}{l}\text { Classification of } \\
\text { Aggregate }\end{array}$} & \multicolumn{10}{|c|}{ Strengthening Effect } & \multirow{4}{*}{ References } \\
\hline & \multicolumn{5}{|c|}{ Recycled Aggregates } & \multicolumn{5}{|c|}{ Recycled Mortar and Recycled Concrete } & \\
\hline & \multicolumn{2}{|c|}{ Bibulous Rate (\%) } & \multicolumn{2}{|c|}{ Porosity (\%) } & \multirow{2}{*}{$\begin{array}{c}\text { Percentage Increase in } \\
\text { Mass (\%) }\end{array}$} & \multicolumn{2}{|c|}{$\begin{array}{l}\text { Compressive } \\
\text { Strength (MPa) }\end{array}$} & \multicolumn{2}{|c|}{$\begin{array}{c}\text { Flexural Strength } \\
\text { (MPa) }\end{array}$} & \multirow{2}{*}{$\begin{array}{c}\text { Percentage Reduction of } \\
\text { Chloride Ion Permeability } \\
\text { Coefficient }(\%)\end{array}$} & \\
\hline & Before & After & Before & After & & Before & After & Before & After & & \\
\hline $\begin{array}{c}\text { Coarse } \\
\text { aggregate }\end{array}$ & $5-5.5$ & $4.5-5$ & 15 & 10 & 0.8 & $44-54$ & $51-76$ & \multicolumn{2}{|c|}{-} & $6.2-10.5$ & {$[50,65,72]$} \\
\hline $\begin{array}{l}\text { Fine } \\
\text { aggregate }\end{array}$ & 24 & 16.5 & & & 2.7 & $\begin{array}{l}29 \\
12\end{array}$ & $\begin{array}{c}38 \\
13.7\end{array}$ & $\begin{array}{c}2.65 \\
1.8\end{array}$ & $\begin{array}{c}3.6 \\
3.32\end{array}$ & - & {$[49,82,83]$} \\
\hline
\end{tabular}


A large number of studies showed that MICP technology used to strengthen recycled aggregate could achieve a significant strengthening effect, and the properties could be significantly improved whether coarse aggregate or fine aggregate was used. However, it should be noted that both the mechanical properties and durability of recycled aggregate concrete (mortar) also need to be further improved. Feng et al. [83] used Sporosarcina pasteurii bacteria to strengthen recycled fine aggregates, and the compressive strength and flexural strength of the recycled mortar increased by $14.3 \%$ and $84.5 \%$, respectively. However, there is still a sharp difference between the compressive strength and flexural strength of natural mortar. The flexural strength was approximately $39.6 \%$ of natural mortar, and the compressive strength was only approximately $28.5 \%$. Similarly, the research results of Muynck et al. [43] on the durability of concrete also indicated that although the MICP technique could effectively improve the chloride ion penetration resistance of recycled concrete, it is still difficult to apply it to structural buildings. At the same time, a large number of studies have shown that the optimal period for the MICP technique to achieve a significant strengthening effect on recycled aggregate is soaking in nutrient solution for continuous mineralization for 14 days (at least 7 days) $[32,47,81]$. The long period of strengthening also greatly limits the application of the MICP technique.

\section{Conclusions and Prospect}

This paper reviewed the influencing factors, strengthening mechanism and effectiveness, and advantages and disadvantages of using the MICP technique to strengthen recycled aggregate. Through a systematic and comprehensive analysis of numerous studies, the following conclusions were drawn:

1. As a relatively new and popular strengthening method in recent years, the MICP technique for modifying recycled aggregate is favored by researchers due to its environmental protection and low energy consumption performance. This technique can obtain a good result for improving the properties of recycled aggregate and concrete, especially microproperties. However, its mineralization period is too long, and almost all studies have shown that it takes more than 7 days to achieve significant effects $[48,81]$. It is difficult to reduce the cost of a culture medium due to the high requirements of a biological culture [45]. All of these factors have limited the development of this technique.

2. Microbial mineralization and deposition occur under the combined action of many factors, such as bacteria, calcium source, medium composition, $\mathrm{pH}$ value, nucleation center location, and temperature. At present, studies on modified aggregates mostly focus on the influence of calcium source, medium composition and $\mathrm{pH}$ value. In fact, as a process of biological growth and metabolism, comprehensive exploration of the optimal range of influencing factors should be the first step before the modification of aggregates. For example, when selecting different strains, the influence of different $\mathrm{pH}$ values on the experimental results should be determined to achieve the best precipitation effect. In particular, there is still no good solution for fixing the nucleation site on the weak spot of the aggregate surface, and the influence of these factors should be considered first to obtain a better modification effect.

3. The mechanism of mineralization precipitation of different types of bacteria is slightly different. Generally, it is the process of generating calcium carbonate. When using the MICP technique to modify recycled aggregate, researchers should choose the most suitable strain according to their own needs and laboratory conditions to achieve the best modification effect.

4. According to current studies, it is difficult to overcome the disadvantages of using the MICP technique, such as consumption of time and lack of pertinence, to strengthen recycled aggregates. In future studies, researchers could try to combine some physical or chemical strengthening methods with the MICP technique for composite strengthening of recycled aggregate according to the mechanism and the advantages and 
disadvantages of different strengthening methods, which may be the development tendency of reinforcing recycled aggregate in the future.

Author Contributions: Writing-Original, C.F., B.C.; writing-Review and editing, C.F., B.C., H.G., Y.H., translation, W.Z. and J.Z. All authors have read and agreed to the published version of the manuscript.

Funding: This research was funded by Henan Provincial Department of Science and Technology Research Project of China (No.212102310566), China Postdoctoral Science Foundation (NO.2018M632774) and Henan Outstanding Foreign Scientists' Workroom (GZS2021003).

Institutional Review Board Statement: Not applicable.

Informed Consent Statement: Not applicable.

Data Availability Statement: Data can be shared upon direct request.

Conflicts of Interest: The authors declare no conflict of interest.

\section{References}

1. Yu, L.; Wu, R. Using graphene oxide to improve the properties of ultra-high-performance concrete with fine recycled aggregate. Constr. Build. Mater. 2020, 259, 120657. [CrossRef]

2. Jin, R.; Li, B.; Zhou, T.; Wanatowski, D.; Piroozfar, P. An empirical study of perceptions towards construction and demolition waste recycling and reuse in China. Resour. Conserv. Recycl. 2017, 126, 86-98. [CrossRef]

3. Kisku, N.; Joshi, H.; Ansari, M.; Panda, S.K.; Nayak, S.; Dutta, S.C. A critical review and assessment for usage of recycled aggregate as sustainable construction material. Constr. Build. Mater. 2017, 131, 721-740. [CrossRef]

4. Gholampour, A.; Ozbakkaloglu, T. Time-dependent and long-term mechanical properties of concretes incorporating different grades of coarse recycled concrete aggregates. Eng. Struct. 2018, 157, 224-234. [CrossRef]

5. McGinnis, M.J.; Davis, M.; de la Rosa, A.; Weldon, B.D.; Kurama, Y.C. Strength and stiffness of concrete with recycled concrete aggregates. Constr. Build. Mater. 2017, 154, 258-269. [CrossRef]

6. Xiao, J.; Li, W.; Fan, Y.; Huang, X. An overview of study on recycled aggregate concrete in China (1996-2011). Constr. Build. Mater. 2012, 31, 364-383. [CrossRef]

7. Evangelista, L.; de Brito, J. Durability performance of concrete made with fine recycled concrete aggregates. Cem. Concr. Compos. 2010, 32, 9-14. [CrossRef]

8. Tangchirapat, W.; Khamklai, S.; Jaturapitakkul, C. Use of ground palm oil fuel ash to improve strength, sulfate resistance, and water permeability of concrete containing high amount of recycled concrete aggregates. Mater. Des. 2012, 41, 150-157. [CrossRef]

9. Guo, H. Characteristics of Carbonated Recycled Concrete Aggregate and Its Effect on the Microstructure and Properties of Recycled Aggregate Concrete. Ph.D. Thesis, Henan Polytechnic University, Jiaozuo, China, 2019.

10. Xuan, D.; Zhan, B.; Poon, C.H. Assessment of mechanical properties of concrete incorporating carbonated recycled concrete aggregates. Cem. Concr. Compos. 2016, 65, 67-74. [CrossRef]

11. Da Silva Neto, G.A.; de Oliveira, J.P.V.; Salles, P.V.; de Vasconcelos Barros, R.T.; Paulino, M.T.; Dos Santos, W.J. Influence of Heterogeneity, Typology, and Contaminants of Recycled Aggregates on the Properties of Concrete. Open Constr. Build. Technol. J. 2021, 14, 382-399. [CrossRef]

12. Adessina, A.; Ben Fraj, A.; Barthélémy, J.; Chateau, C.; Garnier, D. Experimental and micromechanical investigation on the mechanical and durability properties of recycled aggregates concrete. Cem. Concr. Res. 2019, 126, 105900. [CrossRef]

13. Bai, L. Experimental Study on Compressive Strength and Microscopic Properties of Recycled Concrete with Reinforced Coarse Aggregate. Master's Thesis, Xi'an University of Architecture and Technology, Xian, China, 2019.

14. Pepe, M.; Toledo Filho, R.D.; Koenders, E.A.B.; Martinelli, E. Alternative processing procedures for recycled aggregates in structural concrete. Constr. Build. Mater. 2014, 69, 124-132. [CrossRef]

15. Kim, H.; Kim, B.; Kim, K.; Kim, J. Quality improvement of recycled aggregates using the acid treatment method and the strength characteristics of the resulting mortar. J. Mater. Cycles Waste 2017, 19, 968-976. [CrossRef]

16. Menard, Y.; Bru, K.; Touze, S.; Lemoign, A.; Poirier, J.E.; Ruffie, G.; Bonnaudin, F.; Von Der Weid, F. Innovative process routes for a high-quality concrete recycling. Waste Manag. 2013, 33, 1561-1565. [CrossRef] [PubMed]

17. Dimitriou, G.; Savva, P.; Petrou, M.F. Enhancing mechanical and durability properties of recycled aggregate concrete. Constr. Build. Mater. 2018, 158, 228-235. [CrossRef]

18. Kurda, R.; de Brito, J.; Silvestre, J.D. Combined influence of recycled concrete aggregates and high contents of fly ash on concrete properties. Constr. Build. Mater. 2017, 157, 554-572. [CrossRef]

19. Spaeth, V.; Djerbi Tegguer, A. Improvement of recycled concrete aggregate properties by polymer treatments. Int. J. Sustain. Built Environ. 2013, 2, 143-152. [CrossRef]

20. Li, L.; Poon, C.S.; Xiao, J.; Xuan, D. Effect of carbonated recycled coarse aggregate on the dynamic compressive behavior of recycled aggregate concrete. Constr. Build. Mater. 2017, 151, 52-62. [CrossRef] 
21. Wang, L.; Wang, J.; Qian, X.; Chen, P.; Xu, Y.; Guo, J. An environmentally friendly method to improve the quality of recycled concrete aggregates. Constr. Build. Mater. 2017, 144, 432-441. [CrossRef]

22. Dejong, J.T.; Soga, K.; Kavazanjian, E.; Burns, S.; Van Paassen, L.A.; Al Qabany, A.; Aydilek, A.; Bang, S.S.; Burbank, M.; Caslake, L.F.; et al. Biogeochemical processes and geotechnical applications: Progress, opportunities and challenges. Géotechnique 2013, 63, 287-301. [CrossRef]

23. Zhu, T.; Dittrich, M. Carbonate Precipitation through Microbial Activities in Natural Environment, and Their Potential in Biotechnology: A Review. Front. Bioeng. Biotechnol. 2016, 4, 4. [CrossRef]

24. Dong, B.; Liu, S.; Gao, X.; Wang, R. Evaluation of effect of microbial induced steuvite precipition strerngthing calcareous sand in seawater environment. J. Civ. Environ. Eng. 2020, 42. [CrossRef]

25. Gao, Y.; Tang, X.; Chu, J.; He, J. Microbially Induced Calcite Precipitation for Seepage Control in Sandy Soil. Geomicrobiol. J. 2019, 36, 366-375. [CrossRef]

26. Crawford, R.L.; Burbank, M.B.; Weaver, T.J.; Williams, B.C. In Situ Precipitation of Calcium Carbonate (CaCO3) by Indigenous Microorganisms to Improve Mechanical Properties of a Geomaterial. U.S. Patent 8,420,362, 16 April 2013.

27. Wiktor, V.; Jonkers, H.M. Quantification of crack-healing in novel bacteria-based self-healing concrete. Cem. Concr. Compos. 2011, 33, 763-770. [CrossRef]

28. Liu, S.; Yu, S.; Zeng, W.; Peng, X.; Cai, Y.; Tu, B. Repair effect of tabia cracks with microbially induced carbonate precipitation. Chin. J. Rock Mech. Eng. 2020, 39, 191-204. [CrossRef]

29. Anbu, P.; Kang, C.; Shin, Y.; So, J. Formations of calcium carbonate minerals by bacteria and its multiple applications. Springer Plus 2016, 5, 250. [CrossRef]

30. Benzerara, K.; Miot, J.; Morin, G.; Ona-Nguema, G.; Skouri-Panet, F.; Férard, C. Significance, mechanisms and environmental implications of microbial biomineralization. Comptes Rendus Geosci. 2011, 343, 160-167. [CrossRef]

31. Phillips, A.J.; Gerlach, R.; Lauchnor, E.; Mitchell, A.C.; Cunningham, A.B.; Spangler, L. Engineered applications of ureolytic biomineralization: A review. Biofouling 2013, 29, 715-733. [CrossRef] [PubMed]

32. De Muynck, W.; De Belie, N.; Verstraete, W. Microbial carbonate precipitation in construction materials: A review. Ecol. Eng. 2010, 36, 118-136. [CrossRef]

33. García-González, J.; Rodríguez-Robles, D.; Wang, J.; De Belie, N.; Morán-del Pozo, J.M.; Guerra-Romero, M.I.; Juan-Valdés, A. Quality improvement of mixed and ceramic recycled aggregates by biodeposition of calcium carbonate. Constr. Build. Mater. 2017, 154, 1015-1023. [CrossRef]

34. Dick, J.; De Windt, W.; De Graef, B.; Saveyn, H.; Van der Meeren, P.; De Belie, N.; Verstraete, W. Bio-deposition of a calcium carbonate layer on degraded limestone by Bacillus species. Biodegradation 2006, 17, 357-367. [CrossRef]

35. De Muynck, W.; Debrouwer, D.; De Belie, N.; Verstraete, W. Bacterial carbonate precipitation improves the durability of cementitious materials. Cem. Concr. Res. 2008, 38, 1005-1014. [CrossRef]

36. Gebru, K.A.; Kidanemariam, T.G.; Gebretinsae, H.K. Bio-cement production using microbially induced calcite precipitation (MICP) method: A review. Chem. Eng. Sci. 2021, 238, 116610. [CrossRef]

37. Dhami, N.K.; Reddy, M.S.; Mukherjee, A. Biomineralization of calcium carbonates and their engineered applications: A review. Front. Microbiol. 2013, 4, 314. [CrossRef] [PubMed]

38. Amer, F.; Mahmoud, M.A.; Sabet, V. Zeta Potential and Surface Area of Calcium Carbonate as Related to Phosphate Sorption1. Soil Sci. Soc. Am. J. 1985, 49, 1137-1142. [CrossRef]

39. Mahawish, A.; Bouazza, A.; Gates, W.P. Effect of particle size distribution on the bio-cementation of coarse aggregates. Acta Geotech. 2018, 13, 1019-1025. [CrossRef]

40. Grabiec, A.M.; Klama, J.; Zawal, D.; Krupa, D. Modification of recycled concrete aggregate by calcium carbonate biodeposition. Constr. Build. Mater. 2012, 34, 145-150. [CrossRef]

41. Zhan, M.; Pan, G.; Wang, Y.; Fu, M.; Lu, X. Recycled aggregate mortar enhanced by microbial calcite precipitation. Mag. Concr. Res. 2020, 72, 622-633. [CrossRef]

42. Achal, V.; Pan, X. Influence of Calcium Sources on Microbially Induced Calcium Carbonate Precipitation by Bacillus sp. CR2. Appl. Biochem. Biotechnol. 2014, 173, 307-317. [CrossRef]

43. De Muynck, W.; Verbeken, K.; De Belie, N.; Verstraete, W. Influence of urea and calcium dosage on the effectiveness of bacterially induced carbonate precipitation on limestone. Ecol. Eng. 2010, 36, 99-111. [CrossRef]

44. De Muynck, W.; Cox, K.; Belie, N.D.; Verstraete, W. Bacterial carbonate precipitation as an alternative surface treatment for concrete. Constr Build. Mater. 2008, 22, 875-885. [CrossRef]

45. Achal, V.; Mukherjee, A.; Basu, P.C.; Reddy, M.S. Lactose mother liquor as an alternative nutrient source for microbial concrete production by Sporosarcina pasteurii. J. Ind. Microbiol. Biot. 2009, 36, 433-438. [CrossRef]

46. Omoregie, A.L.; Ngu, L.H.; Ong, D.E.L.; Nissom, P.M. Low-cost cultivation of Sporosarcina pasteurii strain in food-grade yeast extract medium for microbially induced carbonate precipitation (MICP) application. Biocatal. Agric. Biotechnol. 2019, 17, 247-255. [CrossRef]

47. Whiffin, V.S. Microbial $\mathrm{CaCO}_{3}$ Precipitation for the Production of Biocement. Ph.D. Thesis, Murdoch University, Perth, Australia, 2004.

48. Qiu, J.; Tng, D.Q.S.; Yang, E. Surface treatment of recycled concrete aggregates through microbial carbonate precipitation. Constr. Build. Mater. 2014, 57, 144-150. [CrossRef] 
49. Zeng, W.; Zhao, Y.; Poon, C.S.; Feng, Z.; Lu, Z.; Shah, S.P. Using microbial carbonate precipitation to improve the properties of recycled aggregate. Constr. Build. Mater. 2019, 228, 116743. [CrossRef]

50. Xu, J.; Wang, X.; Yao, W. Coupled effects of carbonation and bio-deposition in concrete surface treatment. Cem. Concr. Compos. 2019, 104, 103358. [CrossRef]

51. Rodriguez-Navarro, C.; Jroundi, F.; Schiro, M.; Ruiz-Agudo, E.; González-Muñoz, M.T. Influence of Substrate Mineralogy on Bacterial Mineralization of Calcium Carbonate: Implications for Stone Conservation. Appl. Environ. Microb. 2012, 78, 4017-4029. [CrossRef]

52. Tobler, D.J.; Cuthbert, M.O.; Greswell, R.B.; Riley, M.S.; Renshaw, J.C.; Handley-Sidhu, S.; Phoenix, V.R. Comparison of rates of ureolysis between Sporosarcina pasteurii and an indigenous groundwater community under conditions required to precipitate large volumes of calcite. Geochim. Cosmochim. Acta 2011, 75, 3290-3301. [CrossRef]

53. Zhu, Y.; Rong, D.; Xu, P.; Chen, F.; Sun, W. Influence of Oxygen Supply Agent Concentration and Soaking Position on MICP Recycled Aggregate Properties. Mater. Rep. 2021, 35, 4074-4078. [CrossRef]

54. Martin, D.; Dodds, K.; Ngwenya, B.T.; Butler, I.B.; Elphick, S.C. Inhibition of Sporosarcina pasteurii under Anoxic Conditions: Implications for Subsurface Carbonate Precipitation and Remediation via Ureolysis. Environ. Sci. Technol. 2012, 46, 8351-8355. [CrossRef]

55. Zamarreño, D.V.; Inkpen, R.; May, E. Carbonate Crystals Precipitated by Freshwater Bacteria and Their Use as a Limestone Consolidant. Appl Environ. Microb. 2009, 75, 5981-5990. [CrossRef]

56. Boquet, E.; Boronat, A.; Ramos-Cormenzana, A. Production of Calcite (Calcium Carbonate) Crystals by Soil Bacteria is a General Phenomenon. Nature 1973, 246, 527-529. [CrossRef]

57. Kim, G.; Kim, J.; Youn, H. Effect of Temperature, pH, and Reaction Duration on Microbially Induced Calcite Precipitation. Appl. Sci. 2018, 8, 1277. [CrossRef]

58. Mathur, S.; Bhatt, A.; Patel, R. Role of Microbial Induced Calcite Precipitation in Sustainable Development. Sch. Res. Libr. 2018, 1, 7-17.

59. Van Paassen, L.A. Ground Improvement by Microbially Induced Carbonate Precipitation. Ph.D. Thesis, Delft University of Technology, Delft, The Netherlands, 2009.

60. Meyers, M.A.; Chen, P.; Lin, A.Y.; Seki, Y. Biological materials: Structure and mechanical properties. Prog. Mater. Sci 2008, 53, 1-206. [CrossRef]

61. Schultze-Lam, S.; Fortin, D.; Davis, B.S.; Beveridge, T.J. Mineralization of bacterial surfaces. Chem. Geol. 1996, 132, 171-181. [CrossRef]

62. Beveridge, T.J. The bacterial surface: General considerations towards design and function. Can. J. Microbiol. 1988, 34, 363-372. [CrossRef] [PubMed]

63. Fujita, Y.; Taylor, J.L.; Gresham, T.L.T.; Delwiche, M.E.; Colwell, F.S.; McLing, T.L.; Petzke, L.M.; Smith, R.W. Stimulation Of Microbial Urea Hydrolysis In Groundwater To Enhance Calcite Precipitation. Environ. Sci. Technol. 2008, 42, 3025-3032. [CrossRef] [PubMed]

64. Siddique, R.; Chahal, N.K. Effect of ureolytic bacteria on concrete properties. Constr. Build. Mater. 2011, 25, 3791-3801. [CrossRef]

65. Wang, J.; Vandevyvere, B.; Vanhessche, S.; Schoon, J.; Boon, N.; De Belie, N. Microbial carbonate precipitation for the improvement of quality of recycled aggregates. J. Clean Prod. 2017, 156, 355-366. [CrossRef]

66. Jonkers, H.M.; Thijssen, A.; Muyzer, G.; Copuroglu, O.; Schlangen, E. Application of bacteria as self-healing agent for the development of sustainable concrete. Ecol. Eng. 2010, 36, 230-235. [CrossRef]

67. Tziviloglou, E.; Wiktor, V.; Jonkers, H.M.; Schlangen, E. Selection of Nutrient Used in Biogenic Healing Agent for Cementitious Materials. Front. Mater. 2017, 4, 15. [CrossRef]

68. Xu, J.; Yao, W. Non-ureolytic Microbiologically-induced Calium Carbonate Precipitation. J. Tongji Univ. Nat. Sci. 2013, 41, 1542-1546. [CrossRef]

69. Plummer, L.N.; Busenberg, E. The solubilities of calcite, aragonite and vaterite in $\mathrm{COrHzO}$ solutions between 0 and $90^{\circ} \mathrm{C}$, and an evaluation of the aqueous model for the system $\mathrm{CaCO}_{3}-\mathrm{CO}_{2}-\mathrm{H}_{2} \mathrm{O}$. Geochim. Cosmochim. Acta 1982, 46, 1011-1040. [CrossRef]

70. Qian, C.; Luo, M.; Pan, Q.; Li, R. Mechanism of Microbially Induced Calcite Precipitation in Self-healing Concrete. J. Chin. Ceram. Soc. 2013, 41, 620-626. [CrossRef]

71. Tripp, B.C.; Smith, K.; Ferry, J.G. Carbonic Anhydrase: New Insights for an Ancient Enzyme. J. Biol. Chem. 2001, 276, 48615-48618. [CrossRef] [PubMed]

72. Smith, K.S.; Ferry, J.G. Prokaryotic carbonic anhydrases. FEMS Microbiol. Rev. 2000, 24, 335-366. [CrossRef]

73. Zeng, X. A Thesis Submitted in Partial Fulfillment of the Requirements for the Degree of Master in Engineering. Master's Thesis, Huazhong University of Science \& Technology, Wuhan, China, 2004.

74. Ren, L.; Qian, C. Restoration of Cracks on Surface of Cement-Based Materials by Carbonic Anhydrase Microbiologically Precipition Calium Carbonate. J. Chin. Ceram. Soc. 2014, 42, 1389-1395. [CrossRef]

75. Yang, Q. Experimental Study on the Sand Soil Solidification Using Carbonic Anhydrase Induced Precipitation. Master's Thesis, Southwest University of Science and Technology, Mianyang, China, 2018.

76. Erşan, Y.Ç.; Verbruggen, H.; De Graeve, I.; Verstraete, W.; De Belie, N.; Boon, N. Nitrate reducing $\mathrm{CaCO}_{3}$ precipitating bacteria survive in mortar and inhibit steel corrosion. Cem. Concr. Res. 2016, 83, 19-30. [CrossRef] 
77. Mondal, S.; Ghosh, A.D. Review on microbial induced calcite precipitation mechanisms leading to bacterial selection for microbial concrete. Constr. Build. Mater. 2019, 22, 67-75. [CrossRef]

78. Wang, L.; Zou, K. Research progress of concrete microbial self-healing technology. Acta Silic. Sin. 2019, 47, 135-145. [CrossRef]

79. Dhami, N.K.; Reddy, M.S.; Mukherjee, A. Application of calcifying bacteria for remediation of stones and cultural heritages. Front. Microbiol. 2014, 5, 304. [CrossRef] [PubMed]

80. Ehrlich, H.L.; Newman, D.K. Geomicrobiology, 5th ed.; CRC Press: Boca Raton, FL, USA, 2009.

81. Singh, L.P.; Bisht, V.; Aswathy, M.S.; Chaurasia, L.; Gupta, S. Studies on performance enhancement of recycled aggregate by incorporating bio and nano materials. Constr. Build. Mater. 2018, 181, 217-226. [CrossRef]

82. Xu, P.; Chen, F.; Li, Q.; Ren, Y.; Wu, C.; Zhu, Y. Effect of Microbial Mineralization Deposition on Interfacial Transition Zone of Recycled Aggregate. Mater. Rep. 2020, 34, 6095-6099. [CrossRef]

83. Feng, Z.; Zhao, Y.; Zeng, W.; Lu, Z.; Shah, S.P. Using microbial carbonate precipitation to improve the properties of recycled fine aggregate and mortar. Constr. Build. Mater. 2020, 230, 116949. [CrossRef] 